\title{
Canopy Nutrient Allocation in Relation to Incident Light in the Tropical Fruit Tree Borojoa patinoi (Cuatr.)
}

\author{
Jonathan Lynch and Alonso González \\ Department of Horticulture, The Pennsylvania State University, University Park, PA 16802
}

\begin{abstract}
Additional index words. phosphorus, nitrogen, photosynthesis
Abstract. The relationship of incident photosynthetically active radiation (PAR) and mineral nutrient allocation was evaluated in canopies of Borojoa patinoi (Cuatr.) growing in the Chocó rainforest of Colombia, South America. Allocation of $P$ in the canopy was positively correlated with incident PAR, principally because of increased leaf frequency (number of leaves per unit volume of canopy) brought about by local branching, with a smaller contribution from increased specific leaf weight (SLW, leaf dry weight per unit leaf area). The chemical fractionation of $P$ within leaves did not respond to incident PAR. Canopy N allocation also was positively correlated with incident PAR because of increased leaf frequency and SLW. The N partitioning to soluble protein rather than chlorophyll was positively correlated with incident PAR. The allocation of $\mathrm{K}, \mathrm{Ca}, \mathrm{Mg}, \mathrm{S}, \mathrm{Mn}$, and Cu also was positively correlated with incident PAR primarily because of increased leaf frequency and secondarily because of increased SLW. The area of individual leaves and the concentration of nutrients in leaf dry weight were not important in determining nutrient allocation responses to incident PAR. Our observations suggest that leaf frequency caused by local branching, followed by changes in SLW, are the primary determinants of canopy nutrient allocation in this tropical fruit tree.
\end{abstract}

An understanding of the physiological factors influencing the efficiency of nutrient acquisition and use by fruit trees may contribute to the sustainability and productivity of fruit production in the United States, where intensive fertilization of orchard crops is of increasing concern as a source of groundwater contamination (Weinbaum et al., 1992) and in the tropics, where tree fruit production is often limited by low soil fertility (Opeke, 1982). The efficiency of nutrient use by plants has been defined in many diverse ways, as discussed recently by Clark (1990). In the present context, we will consider nutrient efficiency in terms of the economic analogy of resource allocation (Bloom et al., 1985), in which an efficient plant allocates limiting resources in a way that optimizes growth-limiting processes, as typified by photosynthetic $\mathrm{C}$ acquisition. In this study, we examined the role of canopy nutrient allocation as a part of overall nutrient efficiency of a tropical fruit tree native to low-P soils.

Leaf $\mathrm{N}$ content often is correlated closely with leaf photosynthetic capacity, because both the light-harvesting apparatus and the $\mathrm{CO}_{2}$-assimilating enzymes have high $\mathrm{N}$ contents (DeJong, 1982, 1983). It has been proposed that $C$ gain within plant canopies would be maximized by preferential partitioning of $\mathrm{N}$ to leaves receiving higher levels of light (Field, 1983; Mooney and Gulmon, 1979). This hypothesis has been supported by observation of the correlation of light and leaf $\mathrm{N}$ content within canopies (CharlesEdwards et al., 1987; DeJong and Doyle, 1985; Hirose and Werger, 1987; Hirose et al., 1988; Klein et al., 1991).

Phosphorus also is important in determining leaf photosynthetic capacity, because of its role in enzyme regulation and in controlling metabolite fluxes (Brooks, 1986; Foyer and Spencer, 1986; Sivak and Walker, 1986). Light and P are relatively scarce

Received for publication 2 July 1992. Accepted for publication 5 Apr. 1993. We thank Johannes van Beem, Ivan Ochoa C., Nubia Rodriguez H., and Clara Inés Quintero G. for technical assistance in the field, the venerable Marcos Longa for skillful canoe navigation on the Calima River, the staff of the Tropical Forestry Center of the Univ. of Tolima, Colombia, for access to the experiment site, and the International Center for Tropical Agriculture for the use of analytical facilities and equipment. The cost of publishing this paper was defrayed in part by the payment of page charges. Under postal regulations, this paper therefore must be hereby marked advertisement solely to indicate this fact. in many environments, and allocation of $\mathrm{P}$ to the more illuminated regions of tree canopies also would be expected to maximize plant C gain. Nutrient allocation to a specific portion of the tree canopy can result from an increase in the number of leaves in that portion of the canopy (leaf frequency) or an increase in the nutrient content per leaf. Under conditions of low P availability, leaves likely are produced with the minimum concentration of $\mathrm{P}$ required for physiological function, suggesting that $\mathrm{P}$ allocation in the canopy would depend more on leaf frequency than on changes in leaf $\mathrm{P}$ content. In contrast, $\mathrm{N}$ allocation is expected to depend more on changes within individual leaves, since chloroplast $\mathrm{N}$ fractions can vary in individual leaves in response to the light environment.

The objectives of this study were to test the following hypotheses: 1) light and $\mathrm{P}$ distribution are correlated in tree canopies; and 2) allocation of $\mathrm{N}$ and $\mathrm{P}$ in tree canopies differ in that $\mathrm{P}$ allocation depends more on changes in leaf frequency rather than physiological changes within leaves.

We tested these hypotheses by measuring incident light and nutrient allocation in the canopy of the tropical tree Borojoa patinoi growing in the Chocó rainforest on the Pacific coast of Colombia, South America. This tree produces large, fleshy fruit that have a high market value in Colombia, where it is believed that these fruit have tonic and aphrodisiac qualities. Colombian government agencies are investigating $B$. patinoi as a component of sustainable agroforestry production systems for the Chocó forest, a unique tropical rainforest rich in biological diversity that is threatened by rapid deforestation, conversion to annual crops, and soil degradation. Borojoa patinoi has large lanceolate leaves typically $\approx 270 \mathrm{~mm}$ long and $\approx 100 \mathrm{~mm}$ wide. Although it is a successful understory species adapted to low-light intensity, $B$. patinoi also adapts to higher light intensities, as evidenced by its occurrence in light gaps, the presence of occasional individuals that emerge from the forest canopy, and its cultivation as a horticultural crop in clearings. The B. patinoi canopy is dense, and there is significant self-shading. Individual shoots in the canopy of B. patinoi are initiated and grow in all parts of the canopy, in deeply shaded areas as well as more peripheral areas exposed to higher light intensity. These characteristics made it an appropriate subject for this study. 


\section{Materials and Methods}

Location. Work was conducted at Bajo Calima $\left(76^{\circ} 56^{\prime} \mathrm{W}\right.$, $\left.3^{\circ} 59^{\prime} 30^{\prime \prime} \mathrm{N}\right)$, Municipio of Buenaventura, Dept. of Valle del Cauca, at $\approx 40 \mathrm{~m}$ above mean sea level in the Chocó rainforest on the Pacific Coast of Colombia, South America. This site is characterized by an average annual precipitation of $7600 \mathrm{~mm}$, average annual temperature of $26.4 \mathrm{C}$, and average annual relative humidity of $94 \%$. Soils in the region are generally formed from weathered parent material of low fertility.

Soil analysis. The experiment site's soil was chemically analyzed to reveal imbalances or irregularities in the availability of the nutrients being studied in the tree canopies. Soil samples were collected with a $100-\mathrm{mm}$ auger from three sites within $2 \mathrm{~m}$ of the base of the tree used in the first study, then were pooled and analyzed for $\mathrm{P}$ fractionation according to the method of Williams (1967) and P fixation according to the method of Fassbender and Igue (1967). Standard chemical analyses of tropical soils were performed as described in Salinas and Garcia (1985).

Plant material. The trees used in this study were 4 to 6 years old, reproductively mature, and $\approx 4 \mathrm{~m}$ high, growing in a light gap created by recent anthropogenic clearing of the surrounding 5 to 10 $\mathrm{m}$ of forest.

Canopy measurement of photosynthetically active radiation $(P A R)$. Data reported here represent two sampling periods, the first a detailed study of leaves within a single tree in June 1988, and the second a sampling of five trees from the same location in Mar. 1990. In 1988, 17 leaves were selected from various parts of the canopy with diverse light exposure. We selected the youngest fully expanded leaf on a given branch and avoided leaves showing signs of severe insect herbivory or fungal growth. At 0.5-h intervals, incident PAR was measured at each leaf location over two continuous photoperiods (an afternoon, a complete day, and a morning). Incident PAR was measured with a quantum sensor on a photometer (model Li-188B; LI-COR, Lincoln, Neb.) placed parallel to the leaf adaxial surface and moved back and forth along the midrib of the leaf. Each measurement was integrated for $10 \mathrm{sec}$. All measurements for a given leaf were numerically integrated to provide values for total incident PAR over the entire measurement interval. Ambient PAR was measured at a height of $2.5 \mathrm{~m}$ around the periphery of the canopy.

For the survey of five trees in 1990, 12 leaves were selected in each tree to represent shaded, intermediate, and nonshaded regions of the canopy. Incident PAR for each of the 60 leaves was measured as described previously at midmorning (local time, $\approx 0900 \mathrm{HR})$, noon $(\approx 1200 \mathrm{HR})$, and afternoon $(\approx 1500 \mathrm{HR})$ in one photoperiod. Immediately following each leaf measurement, ambient PAR was measured as described previously to provide an estimate of leaf irradiation as a percentage of ambient PAR. Mean daily PAR as a percentage of ambient PAR was used to group the leaves in one of three categories: 'low light,' corresponding to leaves receiving $30 \%$ or less of ambient PAR, 'medium light' leaves receiving $>30 \%$ to $60 \%$ of ambient PAR, and 'high light' leaves receiving $>60 \%$ of ambient PAR.

Leaf composition. After the final PAR measurements had been taken, leaves used in both sampling periods were cut from the plant and quickly frozen on dry ice. Chlorophyll a and b were extracted from $4.16-\mathrm{cm}^{2}$ leaf discs in $96 \%$ ethanol in darkness at $4 \mathrm{C}$ and quantified spectrophotometrically by the method of Wintermans and Mots (1965). Leaf soluble protein was extracted with $0.05 \mathrm{M}$ tris- $\mathrm{HCl}$ at $\mathrm{pH} 8.8$ containing $200 \mathrm{~g}$ sucrose and $50 \mathrm{~g}$ PVP-40/liter (Robinson and Megarrity, 1975, modified) and determined by the method of Bradford (1976). Lyophilized tissue was analyzed for crude P fractions using the method of Barr and Ullrich (1963). Leaf total $\mathrm{N}$ was determined by the method of Bremner (1965). Leaf content of other elements was determined by digestion (Chapman and Pratt, 1961), followed by atomic absorption spectrophotometry (total $\mathrm{Ca}, \mathrm{Mg}, \mathrm{K}, \mathrm{Zn}, \mathrm{Cu}, \mathrm{Fe}$, and $\mathrm{Mn}$, using the method of Baker and Smith, 1973), turbidometry (total S, using the method of Tabatabai and Bremner, 1970), and colorimetry (total P, using the method of Murphy and Riley, 1962). Throughout this report, we use 'leaf content' to refer to nutrient content per unit leaf area and the traditional 'leaf concentration' to refer to nutrient content per unit leaf dry weight.

Leaf $\mathrm{CO}_{2}$ assimilation. Leaf $\mathrm{CO}_{2}$ assimilation was measured in the field with a portable photosynthesis system (model LI-6000; LI-COR). Because of the high ambient humidity, transpiration and related variables were not measured. For high-light measurements, supplemental illumination of 800 to $900 \mu \mathrm{mol}$ photon $\cdot \mathrm{m}^{-2} \cdot \mathrm{s}^{-1}$ was provided by a hand-held, 12-V metal halide lamp. Leaves were enclosed in the LI-COR 4-liter gas exchange chamber for 40 to 60 sec to measure $\mathrm{CO}$, depletion, during which time there were no changes in leaf temperature, air temperature, or relative humidity. Dark respiration of $\mathrm{CO}_{2}$ was measured by enclosing the leaf chamber in a black cloth.

Data analysis. Tree canopies function in three dimensions, whereas nutrient analysis is expressed typically in units without dimension (nutrient concentration) or having two dimensions (nutrient content per unit leaf area or land area). To quantitatively estimate nutrient allocation within a canopy, we developed a characteristic we call "volumetric nutrient allocation" (VNA), calculated as the product of the various components contributing to total canopy nutrient allocation, as follows: VNA $=$ (nutrient concentration $) \times($ specific leaf weight $) \times($ average leaf area $) \times($ leaf frequency), where "leaf frequency" is defined as the number of leaves present in a given volume of the canopy (and "presence" is defined as at least $50 \%$ of the leaf within the given volume). Leaf frequency is a function of the frequency of major branches, local branching (leading to changes in the frequency of growing shoots), leaf spacing on growing shoots, and leaf duration. The relative contribution of leaf frequency to total VNA will depend in part on the volume of space in which leaves are counted. In this study, leaves were counted in spheres having a $180-\mathrm{mm}$ radius.

Statistical analysis. The relationship of VNA with the components used in calculating VNA was analyzed by Pearson linear correlation of standardized log-transformed variables. Standardization was necessary to eliminate the impact of unit magnitude on the correlations. Correlation was used instead of regression, because none of the variables was independently controlled; a leastsquares approach was indicated to reduce the influence of outliers and error on fundamental relationships. Log transformations were used to reduce problems of autocorrelation and to help linearize the data before correlation. The relationship of light classes and leaf frequency was analyzed as a randomized complete block design with trees as blocks (Wilkinson, 1989). Relationships of leaf characteristics with incident light were analyzed by Pearson linear correlation, because incident light and observed leaf characteristics were dependent variables. Resulting correlation coefficients are conservative, because in some cases the relationships do not appear linear (yet are not amenable to nonlinear regression analysis since, as noted above, there is no independent variable).

\section{Results}

The study site's soil was moderately acid, was low in readily available P (shown by Bray I and Bray II values, and the values for 
Table 1. Chemical analyses of soil samples from the study site.

\begin{tabular}{|c|c|c|c|c|}
\hline & \multicolumn{4}{|c|}{ Depth (cm) } \\
\hline & 0 to 25 & 25 to 40 & 40 to 50 & 50 to 70 \\
\hline \multicolumn{5}{|l|}{$\overline{\mathrm{P}\left(\mathrm{mg} \cdot \mathrm{kg}^{-1}\right)}$} \\
\hline Bray I & 1.59 & 2.59 & 1.59 & 1.85 \\
\hline Bray II & 2.20 & 3.29 & 2.06 & 2.38 \\
\hline Exchangeable $\mathrm{P}^{z}$ & 5.0 & 6.0 & 5.5 & 5.0 \\
\hline Ca compounds-apatitic & 19.0 & 17.0 & 14.0 & 15.0 \\
\hline Ca compounds-nonapatiti & tic 5.0 & 5.0 & 5.5 & 6.0 \\
\hline Al compounds & 5.5 & 6.0 & 7.5 & 5.0 \\
\hline Fe compounds & 73.5 & 53.0 & 33.5 & 47.0 \\
\hline Inert & 77.0 & 79.3 & 76.5 & 30.7 \\
\hline Organic & 263.7 & 167.3 & 137.5 & 113.7 \\
\hline Total & 448.7 & 333.5 & 280.0 & 222.5 \\
\hline P fixation (\%) & 20.9 & 20.9 & 26.0 & 39.8 \\
\hline $\mathrm{N}\left(\mathrm{mg} \cdot \mathrm{kg}^{-1}\right)$ & 6.50 & 4.26 & 2.69 & 1.79 \\
\hline Organic matter (\%) & 8.02 & 6.16 & 4.08 & 2.82 \\
\hline $\mathrm{K}(\mathrm{meq} / 100 \mathrm{~g})$ & 0.13 & 0.08 & 0.05 & 0.04 \\
\hline $\mathrm{Ca}(\mathrm{meq} / 100 \mathrm{~g})$ & 3.05 & 2.02 & 1.08 & 1.04 \\
\hline $\mathrm{Mg}(\mathrm{meq} / 100 \mathrm{~g})$ & 1.57 & 1.14 & 0.58 & 0.39 \\
\hline $\mathrm{Al}(\mathrm{meq} / 100 \mathrm{~g})$ & 1.08 & 1.58 & 1.83 & 1.83 \\
\hline Al saturation (\%) & 18.5 & 32.8 & 51.7 & 55.5 \\
\hline $\mathrm{Mn}\left(\mathrm{mg} \cdot \mathrm{kg}^{-1}\right)$ & 77.7 & 61.6 & 45.1 & 32.4 \\
\hline $\mathrm{pH}$ & 5.15 & 5.11 & 5.04 & 5.12 \\
\hline $\mathrm{CEC}(\mathrm{meq} / 100 \mathrm{~g})$ & 5.83 & 4.82 & 3.54 & 3.0 \\
\hline
\end{tabular}

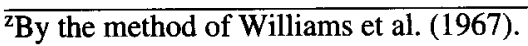

exchangeable $\mathrm{P}$ from the $\mathrm{P}$ fractionation data), and had potentially toxic levels of $\mathrm{Mn}$ in the topsoil and $\mathrm{Al}$ in the subsoil (Table 1). The high organic matter content of the topsoil would suggest that $\mathrm{N}$ was less limiting than $\mathrm{P}$, although without more complete data on $\mathrm{N}$ turnover, this is speculative. The high organic matter content at all depths, together with the high proportion of $\mathrm{P}$ complexed with organic matter, suggests that the soil parent material was allophane-rich alluvium derived from volcanic soils of the nearby western range of the Andes. Fixation of $\mathrm{P}$ was moderate, probably mainly to organic matter-Al complexes. Fair amounts of apatitic $\mathrm{P}$ suggest that rhizosphere modification by plants roots might be useful in liberating $\mathrm{P}$ in this soil. Base supply and $\mathrm{pH}$ did not appear overly problematic for humid tropical vegetation, with the possible exception of low $\mathrm{K}$ availability.

During the first period of measurement (1988), ambient PAR above the canopy averaged $289 \mu \mathrm{mol}$ photon $\cdot \mathrm{m}^{-2} \cdot \mathrm{s}^{-1}$, with a maximum of $556 \mu \mathrm{mol}$ photon $\cdot \mathrm{m}^{-2} \cdot \mathrm{s}^{-1}$. Integrated incident PAR upon the leaves selected for this study ranged from $\approx 2$ to $10 \mathrm{~mol}$ photon $\cdot \mathrm{m}^{-2}$ over the measurement period.

Incident PAR was not correlated with leaf P concentration (Fig. 1). Leaf inorganic $P$, trichloroacetic acid (TCA)-soluble organic $P$, and TCA-insoluble $\mathrm{P}$ fractions were not correlated with changes in incident PAR (33.9\% inorganic, $11.7 \%$ TCA-soluble organic, and $54.4 \%$ TCA-insoluble). Leaf $\mathrm{N}$ and leaf chlorophyll were negatively correlated with incident PAR. Leaf soluble protein concentration was positively correlated with incident PAR.

Specific leaf weight (SLW, dry weight per unit leaf area) increased with increasing PAR (Fig 2). Because of the correlation

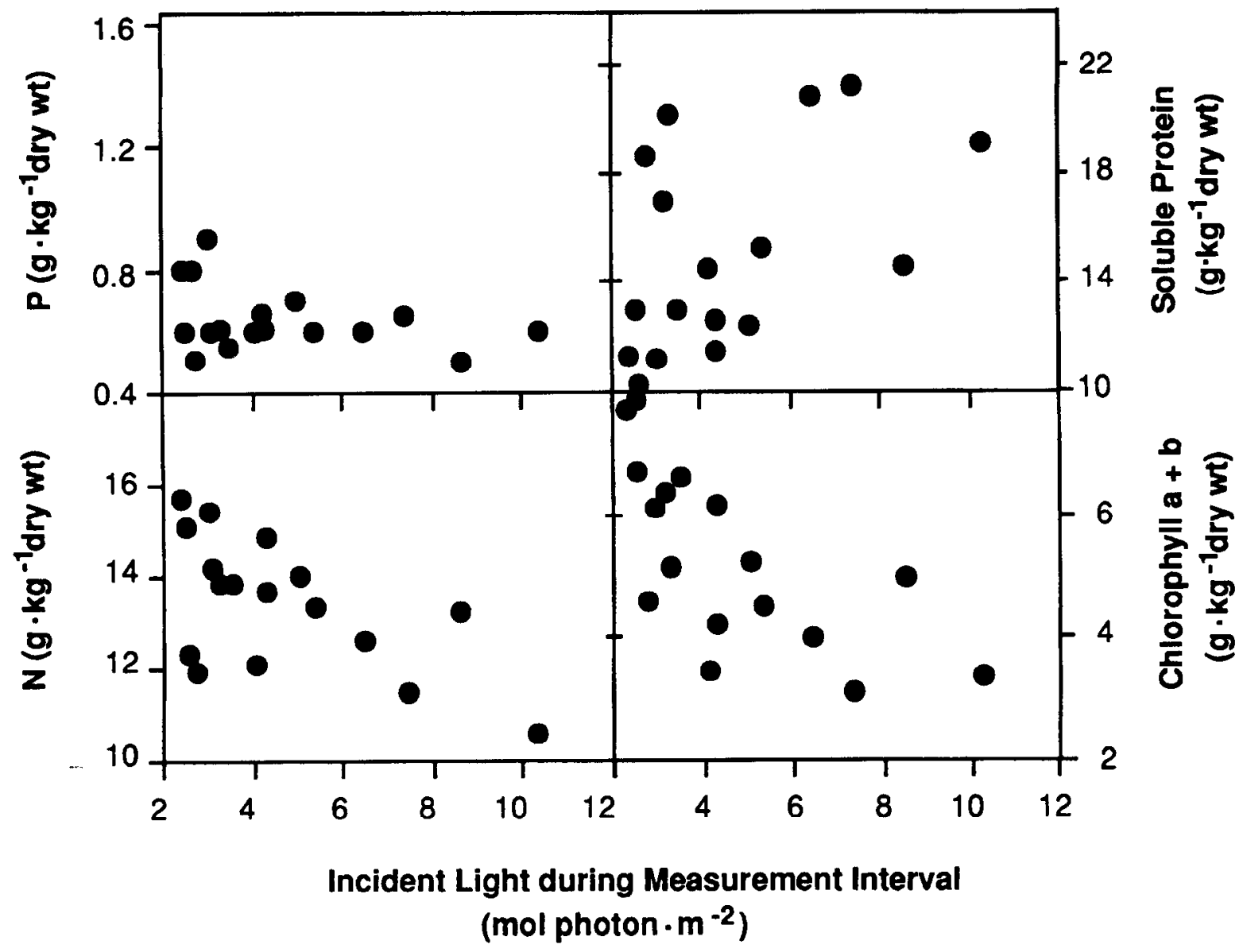

Fig. 1. Total P, total N, soluble protein, and chlorophyll concentration in individual leaves within a canopy of $B$. patino i in relation to incident photosynthetically active radiation (PAR) over 2 days in 1988. Incident PAR was not correlated with $P$ concentration, negatively correlated with $\mathrm{N}$ concentration $(r=-0.59, P \leq 0.01)$, positively correlated with soluble protein concentration $(r=0.48, P \leq 0.05)$, and negatively correlated with chlorophyll concentration $(r=-0.68, P \leq 0.01)$. 


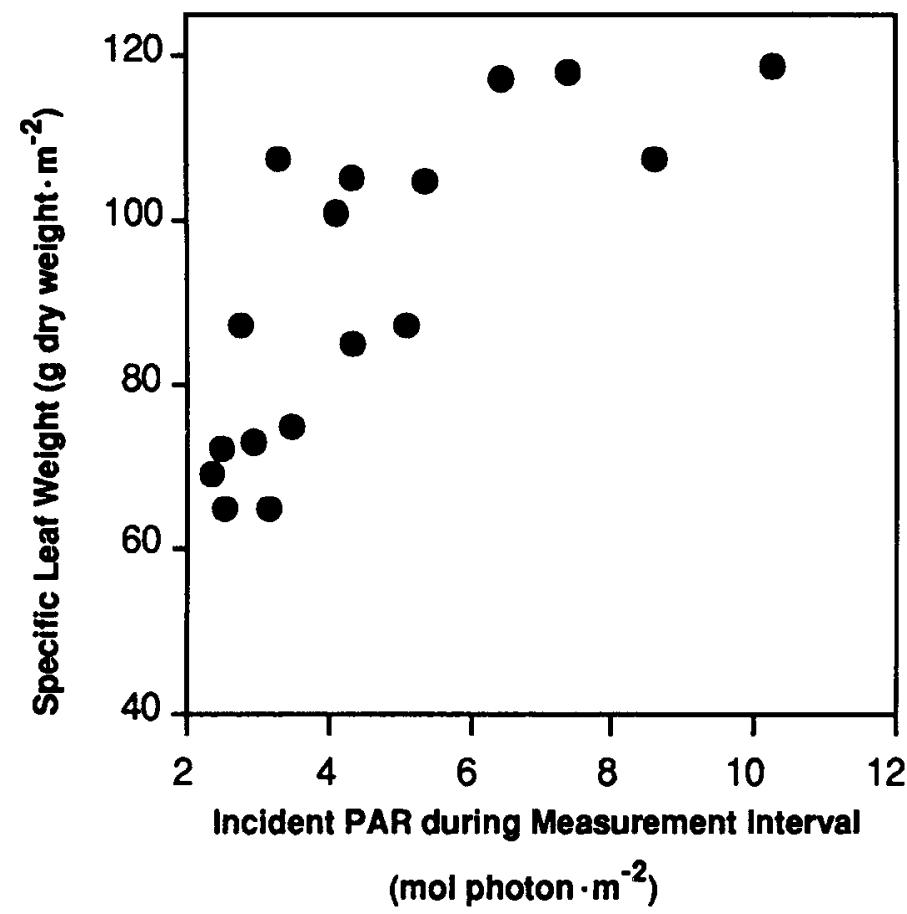

Fig. 2. Specific leaf weight of individual leaves within a canopy of $B$. patinoi in relation to incident photosynthetically active radiation (PAR) over a 2-day period in 1988. $(r=0.79, P=0.0001)$. of SLW with PAR, the relationships of PAR with leaf nutrient concentrations $\left(\mathrm{mg} \cdot \mathrm{kg}^{-1}\right)$ were different than those with leaf nutrient content $\left(\mathrm{mg} \cdot \mathrm{m}^{-2}\right)$. Leaf $\mathrm{P}$ content, leaf $\mathrm{N}$, and leaf soluble protein $\left(\mathrm{mg} \cdot \mathrm{m}^{-2}\right)$ were positively correlated with PAR (Fig. 3). Leaf chlorophyll content $\left(\mathrm{mg} \cdot \mathrm{m}^{-2}\right)$ declined slightly and was not correlated with increasing PAR (Fig. 3).

Leaf $\mathrm{N}$ content $\left(\mathrm{mg} \cdot \mathrm{m}^{-2}\right)$ was not correlated with leaf chlorophyll, but it was positively correlated with soluble protein and leaf $\mathrm{CO}_{2}$ assimilation (Fig. 4). Leaf $\mathrm{CO}_{2}$ assimilation was measured at ambient PAR levels; thus, it is possible that the relationship between leaf $\mathrm{N}$ content and leaf $\mathrm{CO}_{2}$ assimilation was due to the observed relationship between leaf $\mathrm{N}$ content and incident PAR (Fig. 3). We returned to the tree at a later date with portable 12-V halogen lamps that permitted photosynthetic saturation at 800 to $900 \mu \mathrm{mol}$ photon $\cdot \mathrm{m}^{-2} \cdot \mathrm{s}^{-1}$ (data not shown). These later measurements demonstrated that leaf $\mathrm{CO}_{2}$ assimilation at ambient PAR was not substantially less than leaf $\mathrm{CO}_{2}$ assimilation at high PAR, and that these assimilation rates were highly correlated with each other (Fig. 5). Leaf $\mathrm{CO}_{2}$ respiration in darkness was not correlated with the PAR environment of the leaf (data not shown).

Leaf frequency, measured as the number of leaf blades within a sphere originating at the insertion point of the reference leaf and extending out in all directions to a radius of $18 \mathrm{~cm}$, was positively correlated with incident PAR (Fig. 6). Changes in leaf frequency were not associated with differences in internode length or the proximity of major branches (data not shown), but they were associated strongly with the degree of local branching. Of the

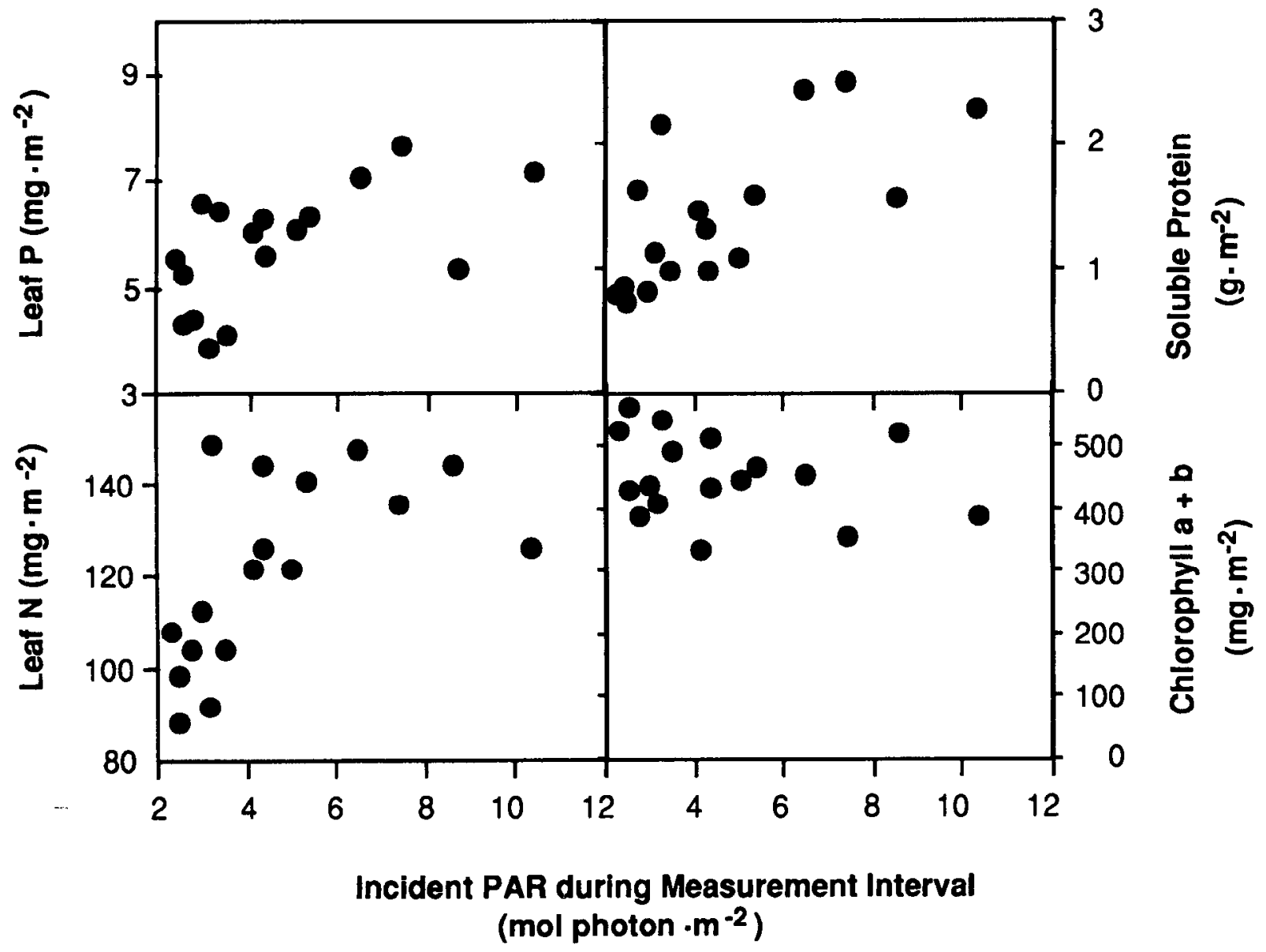

Fig. 3. Total P, total N, soluble protein, and chlorophyll content per unit leaf area in individual leaves within a canopy of $B$. patino in relation to incident photosynthetically active radiation (PAR) over 2 days in 1988. Incident PAR was positively correlated with $\mathrm{P}$ content $(r=0.58, P \leq 0.05), \mathrm{N}$ content $(r=0.59, P \leq 0.05)$, and soluble protein content $(r=0.68, P \leq 0.01)$, but was not significantly correlated with chlorophyll content. 
seven shoots in heavily self-shaded regions of the canopy, all seven were unbranched, whereas of nine shoots selected at random from well-illuminated regions at the periphery of the canopy, eight had branches at the third or fourth node from the apex. Analysis of variance indicated that PAR environment had no effect on internode length (measured with a ruler).

The VNA for $\mathrm{P}$ and $\mathrm{N}$ were positively correlated with incident PAR (Fig. 7), largely because of the high correlation between leaf frequency and PAR, with a secondary contribution from increased nutrient content per unit area because of increased SLW (Table 2). Because VNA is defined as the product of nutrient concentration, SLW, leaf area, and leaf frequency, it was not possible to determine statistically which of these four variables was most important in controlling VNA responses to light; however, the variation in each of these components of VNA may be an indication of their relative impact. Variables that hold constant will, likewise, not account for much change in VNA in response to light, but high variability [indicated in Table 2 by a high coefficient of variation (cv)] also
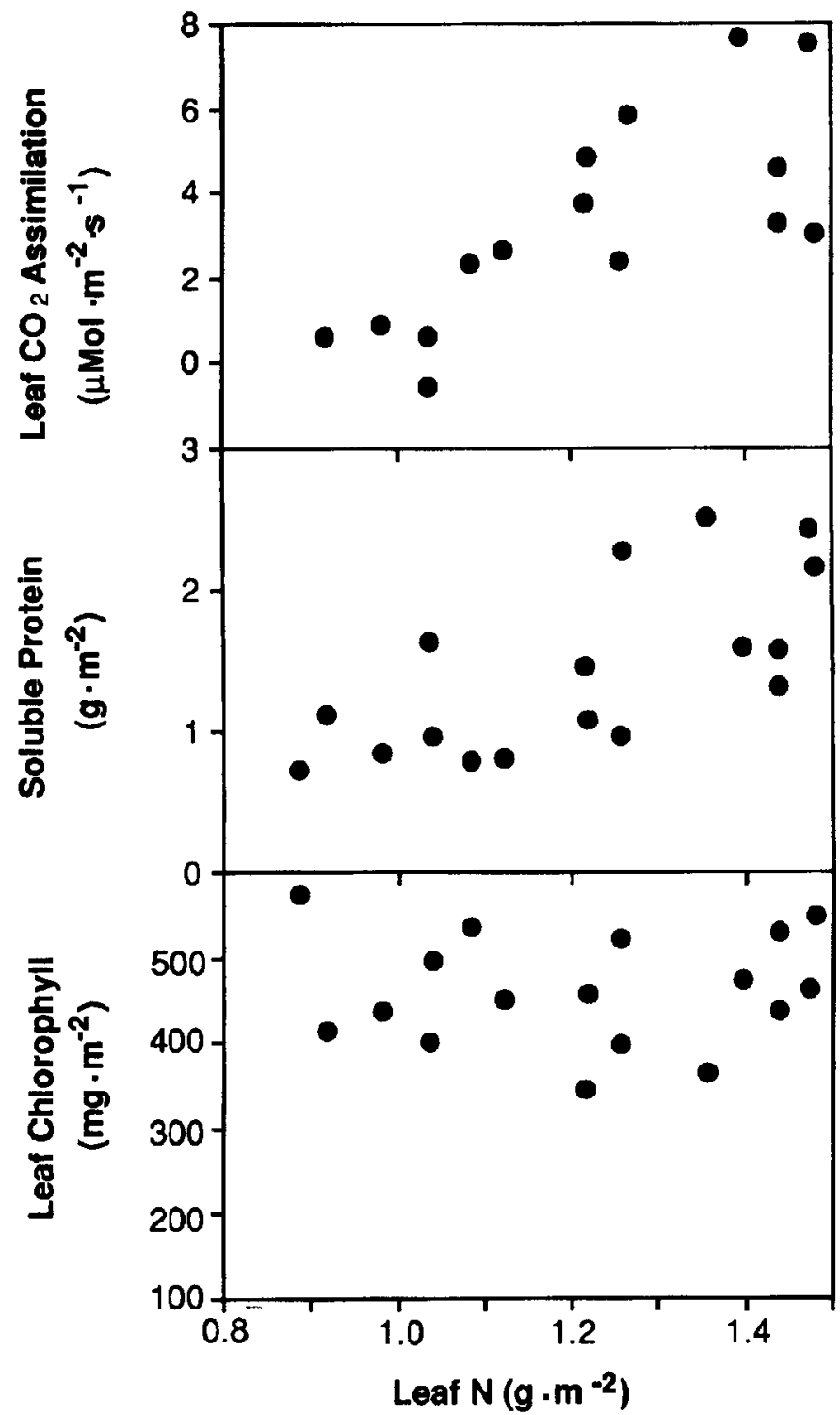

Fig. 4. Relationships per unit leaf area of soluble protein content, chlorophyll content, and $\mathrm{CO}_{2}$ assimilation to $\mathrm{N}$ content in individual leaves within a canopy of $B$. patinoi. Nitrogen content was not significantly correlated with chlorophyll content, but was positively correlated with soluble protein content $(r=0.69, P$ $\leq 0.01$ ), and leaf $\mathrm{CO}_{2}$ assimilation $(r=0.75, P \leq 0.001)$.

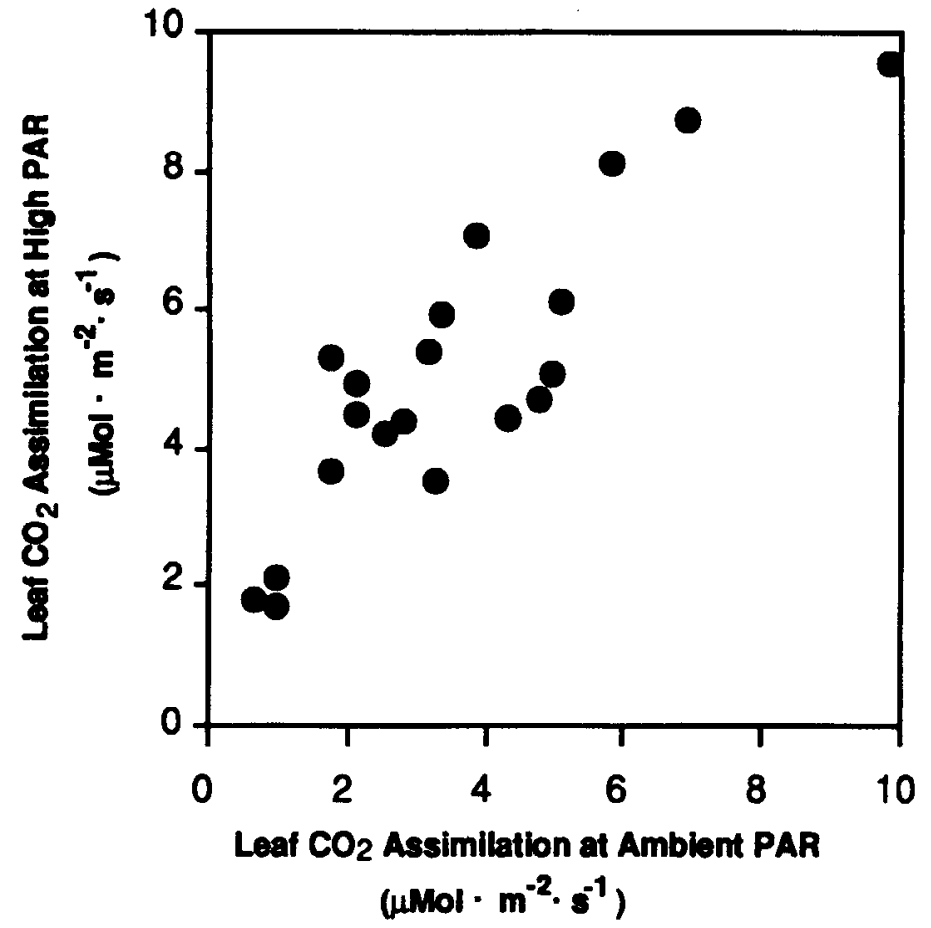

Fig. 5. Carbon dioxide assimilation per unit leaf area at saturating PAR ( 800 to 900 $\mu \mathrm{mol}$ photon $\left.\cdot \mathrm{m}^{-2} \cdot \mathrm{s}^{-1}\right)$ in relation to $\mathrm{CO}_{2}$ assimilation per unit leaf area at ambient photosynthetically active radiation (PAR) $\left(0.1\right.$ to $285 \mu \mathrm{mol}$ photons $\cdot \mathrm{m}^{-2} \cdot \mathrm{s}^{-1}$, with an average of $99 \mu \mathrm{mol}$ photons $\cdot \mathrm{m}^{-2} \cdot \mathrm{s}^{-1}$ ) in individual leaves within a canopy of $B$. patinoi. Leaf $\mathrm{CO}_{2}$ assimilation in ambient and saturating PAR were highly correlated $(r=0.87, P \leq 0.0001)$.

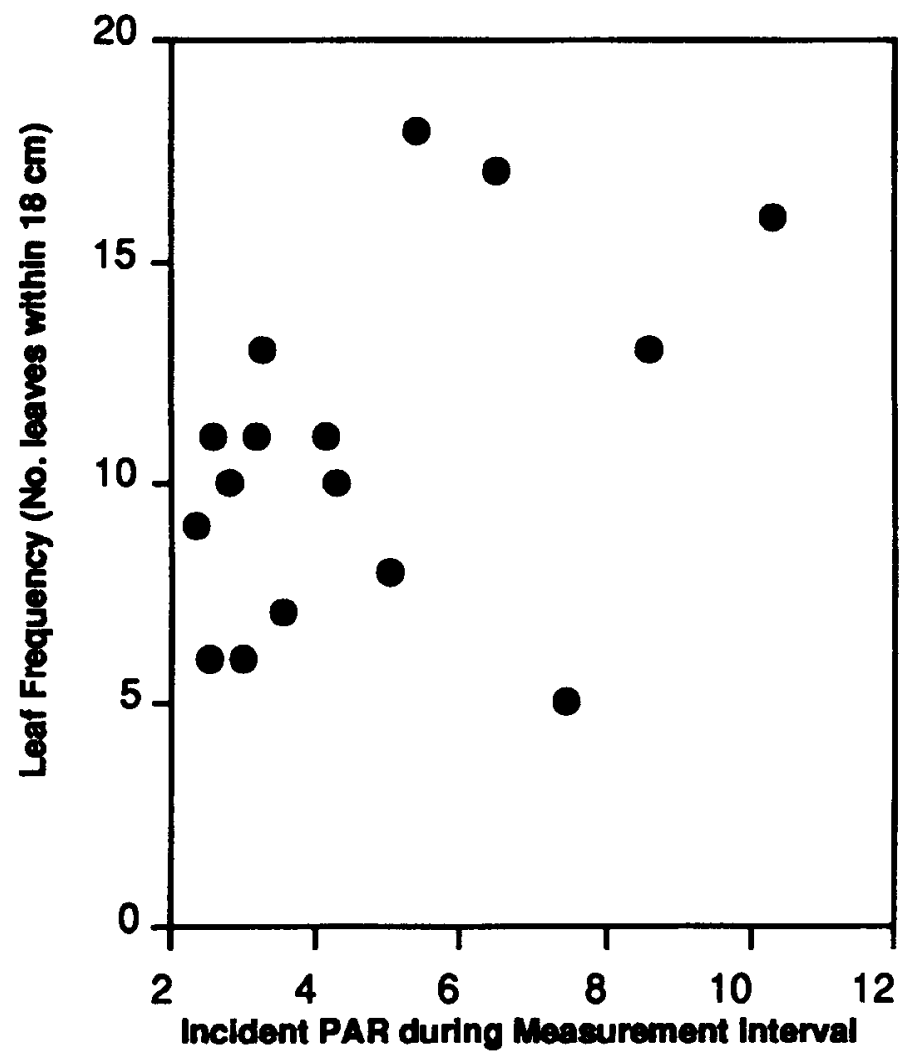

(mol photon $\mathrm{m}^{-2}$ )

Fig. 6. Leaf frequency (number of leaf blades within $18 \mathrm{~cm}$ of the point of insertion of the reference leaf) within a canopy of $B$. patino in relation to incident photosynthetically active radiation (PAR) over a 2-day period in 1988. Leaf frequency was positively correlated with incident $\operatorname{PAR}(r=0.64, P \leq 0.05)$. 


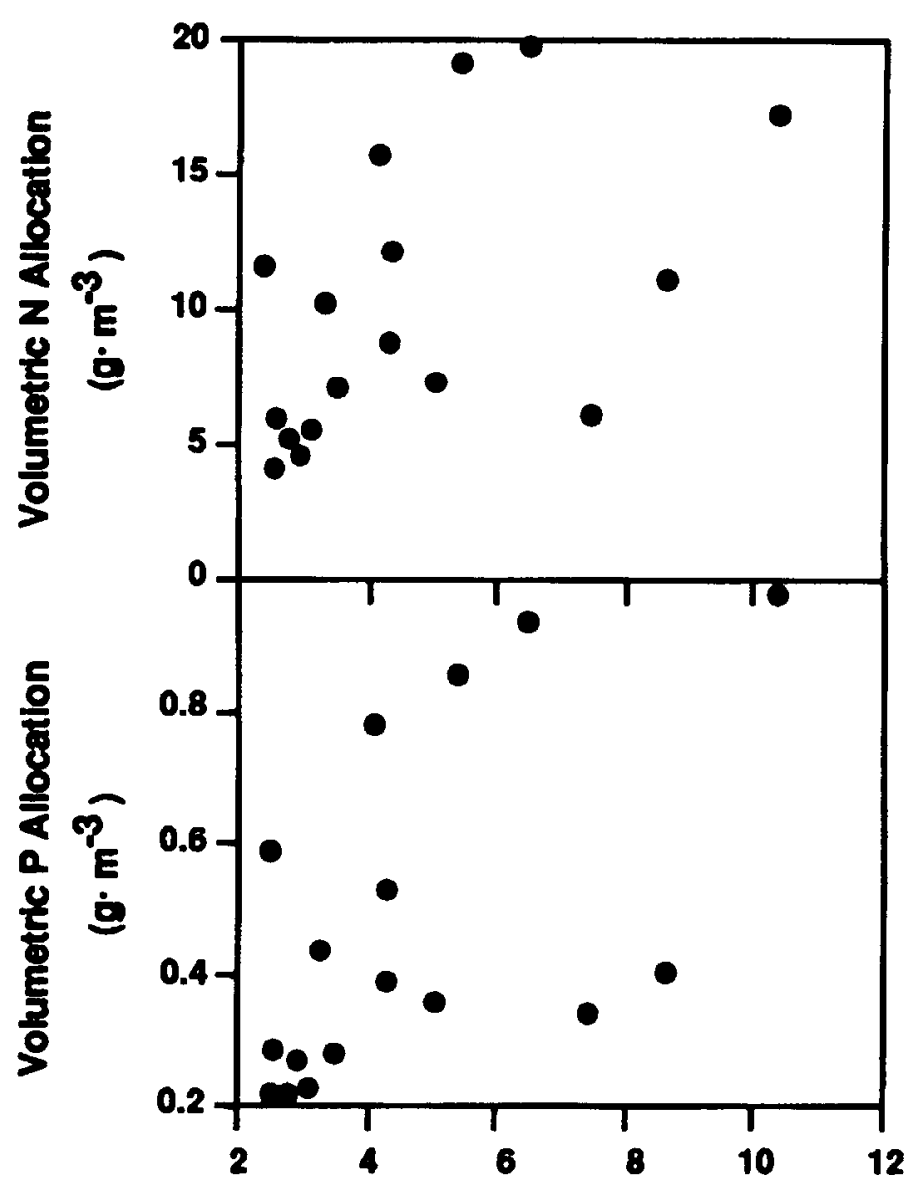

Incident PAR during Measurement Interval (mol photon $\cdot \mathbf{m}^{-2}$ )

Fig. 7. Volumetric nutrient allocation of $\mathbf{N}$ and $\mathrm{P}$ within a canopy of $\boldsymbol{B}$, patinoi in relation to incident photosynthetically active radiation (PAR) over a 2-day period in 1988. Incident PAR was positively correlated with volumetric $\mathrm{N}$ allocation $(r$ $=0.52, P \leq 0.05)$ and volumetric $\mathbf{P}$ allocation $(r=0.55, P \leq 0.05)$.

may be due to noise or variation not associated directly with changes in VNA. Visual examination of the relationship of the four component variables and VNA showed that leaf frequency, which typically had the highest cv, was most closely associated with VNA, followed by SLW. Leaf area had a relatively high cv but was not closely associated with VNA. Leaf concentrations of chlorophyll, N, P, Mg, and S had low cvs and were not associated with VNA, while other nutrients had fairly high cvs but were not associated with VNA. These relationships are shown for $\mathrm{N}$ (representative of a nutrient having a relatively invariant leaf concentration as shown by low cvs) and Fe (representative of a nutrient having a relatively variable leaf concentration as shown by high cvs) (Fig. 8). The contribution of nutrient content per unit area to total VNA was greater for $\mathrm{N}$ than for P. Volumetric soluble protein allocation was positively correlated with incident PAR, because of significant correlations with leaf frequency, specific leaf weight, and soluble protein concentration. Volumetric chlorophyll allocation was not correlated with incident PAR. The volumetric allocations of $\mathrm{S}, \mathrm{Ca}, \mathrm{Mg}, \mathrm{Fe}, \mathrm{Mn}, \mathrm{Zn}$, and $\mathrm{Cu}$ were positively associated with incident PAR, primarily because of leaf frequency. The volumetric allocation of $\mathrm{Ca}$ and $\mathrm{Mg}$ were substantially influenced by nutrient content per unit area because of the combined effects of specific leaf weight and nutrient concentration. Sulfur alloca- tion followed the pattern of $\mathrm{N}$ allocation, as expected. Allocation of $\mathrm{Fe}, \mathrm{Mn}, \mathrm{Zn}$, and $\mathrm{Cu}$ were largely governed by leaf frequency with a secondary contribution from specific leaf weight. Potassium was the only nutrient whose canopy allocation had no association with incident PAR.

A survey of leaves from five trees (data not shown) confirmed the principal results obtained from the detailed analysis of one canopy described previously; however, in the survey, volumetric $\mathrm{Zn}$ and $\mathrm{K}$ allocations were not correlated with incident PAR, contrary to the study of a single canopy. Total leaf frequency was very highly associated with incident PAR, whereas leaffrequency per shoot axis did not respond to changes in incident PAR (Table 3).

\section{Discussion}

Our data show that the distribution of nutrients and PAR are correlated in the canopy of B. patinoi. The factors responsible for the allocation of $\mathrm{P}$ and total $\mathrm{N}$ in the canopy were generally similar. Allocation of $\mathrm{P}$ and $\mathrm{N}$ in response to PAR did differ in terms of the use of $\mathrm{N}$ and $\mathrm{P}$ within leaves. Leaf $\mathrm{P}$ pools were not responsive to incident PAR, whereas soluble protein content increased with

Table 2. Pearson linear correlation coefficients for incident photosynthetically active radiation (PAR) in relation to volumetric nutrient allocation (VNA) and the components used in calculating VNA in the canopy of $B$. patinoi. VNA values are averages of all light environments.

\begin{tabular}{|c|c|c|c|c|}
\hline Variable $^{\mathrm{z}}$ & Mean & SE & $\mathrm{CV}$ & $r$ \\
\hline Leaf area $\left(\mathrm{m}^{2}\right)$ & 0.0188 & 0.0012 & 26.67 & $0.07^{\mathrm{NS}}$ \\
\hline $\operatorname{SLW}\left(\mathrm{g} \cdot \mathrm{m}^{-2}\right)$ & 91.588 & 4.709 & 21.2 & $0.79^{* * *}$ \\
\hline Leaf frequency $\left(\right.$ no. $\left./ \mathrm{m}^{3}\right)$ & 435.8 & 37.9 & 35.9 & $0.44^{\mathrm{NS}}$ \\
\hline \multicolumn{5}{|c|}{$\operatorname{VNA}\left(\mathrm{g} \cdot \mathrm{m}^{-3}\right)$} \\
\hline Chlorophyll & 3.72 & 0.38 & 42 & $0.33^{\mathrm{NS}}$ \\
\hline Protein & 12.23 & 2.1707 & 73.17 & $0.66^{*}$ \\
\hline $\mathbf{N}$ & 10.077 & 1.26 & 51.5 & $0.52^{*}$ \\
\hline K & 2.799 & 0.329 & 48.52 & $-0.11^{\mathrm{NS}}$ \\
\hline $\mathrm{Ca}$ & 6.8484 & 1.1264 & 67.81 & $0.64^{* *}$ \\
\hline $\mathrm{Mg}$ & 5.5331 & 0.8413 & 62.69 & $0.63^{* *}$ \\
\hline$S$ & 2.9451 & 0.5358 & 75.01 & $0.58^{*}$ \\
\hline $\mathbf{P}$ & 0.4786 & 0.0631 & 54.41 & $0.55^{*}$ \\
\hline $\mathrm{Fe}$ & 0.0558 & 0.0097 & 71.87 & $0.72^{* *}$ \\
\hline Mn & 0.0513 & 0.0096 & 77.46 & $0.64^{* *}$ \\
\hline $\mathrm{Zn}$ & 0.0188 & 0.0032 & 70.59 & $0.66^{* *}$ \\
\hline $\mathrm{Cu}$ & 0.0105 & 0.0016 & 64.13 & $0.6^{*}$ \\
\hline \multicolumn{5}{|l|}{$\begin{array}{l}\text { Nutrient concentration } \\
\left(\mathrm{g} \cdot \mathrm{kg}^{-1} \text { dry weight }\right)\end{array}$} \\
\hline Chlorophyll & 10 & 0.36 & 28.34 & $-0.68^{* *}$ \\
\hline Protein & 15 & 0.9 & 24.62 & $-0.48^{* *}$ \\
\hline $\mathrm{N}$ & 13.4 & 0.3 & 10.69 & -0.59 \\
\hline $\mathbf{K}$ & 4.3 & 0.5 & 50.94 & $0.71^{* * *}$ \\
\hline $\mathrm{Ca}$ & 8.5 & 0.4 & 20.89 & $0.3^{\mathrm{NS}}$ \\
\hline $\mathrm{Mg}$ & 7 & 0.2 & 11.75 & $0.25^{\mathrm{NS}}$ \\
\hline $\mathrm{S}$ & 4.1 & 0.2 & 1.94 & $-0.18^{\mathrm{NS}}$ \\
\hline \multicolumn{5}{|l|}{$\begin{array}{l}\text { Nutrient concentration } \\
\left(\mu g \cdot g^{-1} \text { dry weight }\right)\end{array}$} \\
\hline $\mathrm{P}$ & 600 & 35 & 67.4 & $-0.33^{\mathrm{NS}}$ \\
\hline $\mathrm{Fe}$ & 80.1 & 0.629 & 32.3 & $0.16^{\mathrm{NS}}$ \\
\hline Mn & 69.6 & 3.72 & 22.07 & $0.25^{\mathrm{NS}}$ \\
\hline $\mathrm{Zn}$ & 27.0 & 2.04 & 31.178 & $0.04^{\mathrm{NS}}$ \\
\hline $\mathrm{Cu}$ & 15.3 & 0.842 & 22.70 & $-0.21^{\mathrm{NS}}$ \\
\hline
\end{tabular}

${ }^{2}$ Leaf area $=$ average area of individual leaves; SLW = specific leaf weight; Leaf frequency $=$ leaf frequency in number of leaves per unit volume. Ns,***,*** Nonsignificant or significant at $P<0.05,0.01$, or 0.001 , respectively. 


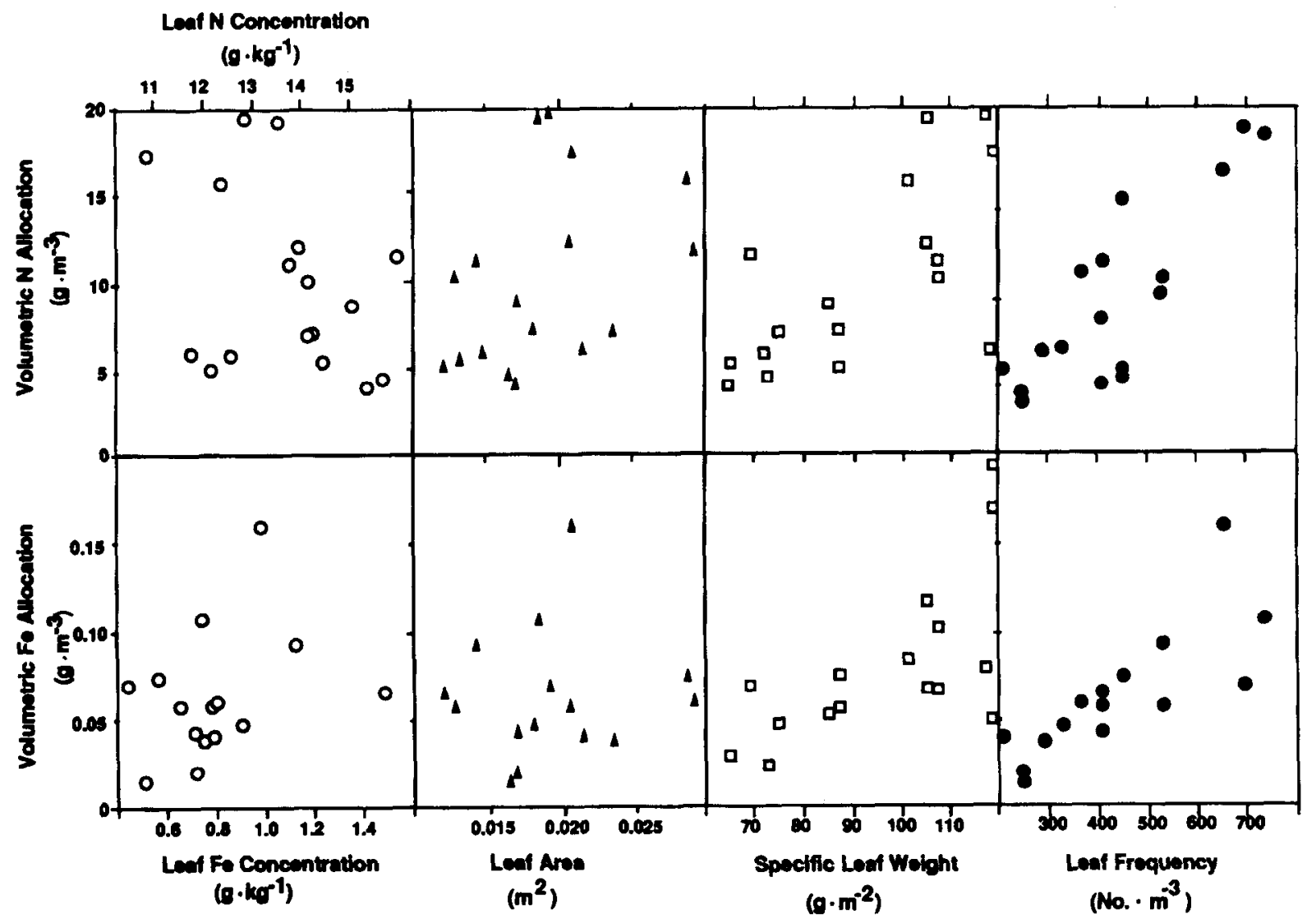

Fig. 8. Relationship of leaf nutrient concentration, leaf area, specific leaf weight, and leaf frequency to volumetric nutrient allocation of $\mathrm{N}$ and Fe within a canopy of $B$. patinoi.

incident PAR, leading to higher ratios of soluble protein : chlorophyll in high light leaves. The divergent responses of soluble protein and chlorophyll allocation to incident PAR is consistent with previous studies (Björkman, 1981; Vapaavuori and Vuorinen, 1989). In low-light environments, the leaf invests more $\mathrm{N}$ in the light harvesting apparatus, because light is limiting photosynthesis, whereas in high-light environments, relatively more $\mathrm{N}$ is devoted to the carboxylation enzymes since at high light, $\mathrm{CO}_{2}$ assimilationis limiting photosynthesis. In $\mathrm{B}$. patinoi, $\mathrm{N}$ investment in light harvesting was a significant component of total $\mathrm{N}$ use, since this species is adapted to low-light levels in the rainforest understory. Our results confirm earlier observations of a correlation of PAR with SLW, and thereby leaf nutrient content in tree canopies (Marini and Marini, 1983; Weinbaum et al., 1989).

Leaf frequency was the most important factor in canopy nutrient allocation. Differences in leaf frequency on a given main branch may have been brought about by differences in the rate of leaf formation, the rate of leaf abscission, leaf spacing, or local branching. One index of leaf age is $\mathrm{Ca}$ content, because $\mathrm{Ca}$ is retranslocated poorly and tends to accumulate in leaves over time. We did not observe a significant correlation between incident PAR and leaf $\mathrm{Ca}$ concentration in mature leaves in the study of one canopy, but did find that high PAR was associated with lower leaf $\mathrm{Ca}$ concentration in the survey of five trees (data not shown). To the extent that leaf $\mathrm{Ca}$ concentration is simply related to leaf age, this is evidence that leaves in higher light environments were younger, which might result from differences in the rate of leaf initiation. However, the fact that incident PAR had no effect on leaf frequency per shoot axis (Table 3) indicates that increased leaf initiation and other mechanisms that would influence leaf frequency per shoot axis were not important in determining the overall response to incident PAR. We did not observe that abscission scars were more frequent or recent on branches in low-light environments, arguing against differential leaf abscission as a determinant of leaf frequency. Our data on leaf spacing (internode length on a given shoot) show no significant differences between light environments. The most important determinant of leaf frequency was local branching. Therefore, processes determining canopy architecture were more important than leaf- or chloroplastrelated processes in nutrient allocation in the canopy of B. patinoi.

Chapin (1980) has proposed that species adapted to lownutrient environments exhibit relatively efficient nutrient use because of slow growth and slow tissue turnover. Our observations of $\mathrm{P}$ allocation in response to local PAR availability support this view, in that the slow 'efficient' growth strategy of $B$. patinoi was conserved at the leaf level even in response to high local PAR intensity. High local PAR intensity was exploited by increased branching, which increases the rate of tissue growth and resource capture in a specific region of the canopy without changing the inherent efficiency characteristics of individual organs, as would be caused by, for example, more rapid leaf turnover.

In considering the implications of the nutrient allocation patterns shown here on $\mathrm{C}$ gain, we note that although the quantum sensor we used measured light in the range of PAR, the spectral distribution of that light would be expected to vary in the canopy, with shadier regions of the canopy having qualitatively poorer light for photosynthesis. The association of light quality with light intensity would tend to amplify the functional significance for photosynthesis of the allocation patterns we report here.

Of the 10 nutrients studied, the distribution of all but $\mathrm{K}$ in the detailed study and $\mathrm{Zn}$ in the survey were correlated with the distribution of PAR, generally in response to increased leaf fre- 
Table 3. Effect of light [photosynthetically active radiation (PAR)] cnvironment on variables related to nutrient allocation in the canopy of B. patinoi. 'Low light' corresponds to leaves receiving $30 \%$ or less of ambient PAR, 'medium light' to leaves receiving from $30 \%$ to $60 \%$ of ambient PAR, and 'high light' to leaves receiving $>60 \%$ of ambient PAR. Data were collected from five trees. Leaf frequency is expressed in terms of the total number of leaves per $\mathrm{m}^{3}$ ('total leaf freq') or only leaves on the same shoot axis as the leaf being measured ('shoot leaf freq'). Data are the mean values.

\begin{tabular}{|c|c|c|c|c|c|c|c|}
\hline \multirow[b]{3}{*}{ Variable } & \multicolumn{6}{|c|}{ Light level } & \multirow[b]{3}{*}{$\mathrm{F}^{\mathrm{z}}$} \\
\hline & \multicolumn{2}{|c|}{ Low } & \multicolumn{2}{|c|}{ Medium } & \multicolumn{2}{|c|}{ High } & \\
\hline & $(\mathrm{N}=28)$ & $\mathrm{SE}$ & $(\mathrm{N}=19)$ & SE & $(N=13)$ & SE & \\
\hline Total leaf frequency & 319 & $(24.6)$ & 577 & (51.6) & 495 & $(36)$ & $12.16^{* * *}$ \\
\hline Shoot leaf frequency & 246 & $(21.3)$ & 319 & (20.9) & 262 & $(26.2)$ & $1.84^{\mathrm{NS}}$ \\
\hline
\end{tabular}

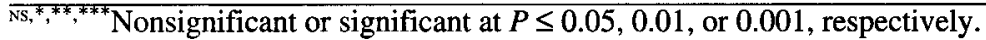

${ }^{2}$ From analysis of variance.

quency and higher specific leaf weight in better-illuminated regions of the canopy. Leaf frequency and specific leaf weight are fundamental variables that simultaneously affect the majority of leaf constituents. Correlation of nutrient and light distribution may or may not represent adaptive behavior in the context of a particular nutrient. We doubt that all of the mineral nutrients have a direct bearing on the photosynthetic capacity of leaf tissue to the extent that $\mathrm{N}$ and $\mathrm{P}$ do. Nutrients such as Ca may simply be an integral component of the cost of leaf production and yield only indirect benefits to canopy $\mathrm{C}$ gain by facilitating optimum $\mathrm{N}$ and $\mathrm{P}$ allocation, rather than through direct contributions.

Bloom et al. (1985) proposed that optimum adaptive behavior consists in balancing resource costs and benefits in such a way that resources are colimiting. Our observations prompt the speculation that optimum use of several principal resources (in this case light, $\mathrm{N}$, and $\mathrm{P}$ ) automatically entails a defined use of a range of other resources (in this case mineral nutrients such as $\mathrm{Ca}, \mathrm{Mg}$, etc.) that otherwise may conceivably have other 'optimum' uses. This pattern implies the existence of resource prioritization. Lower priority resources may not benefit from inherent mechanisms to integrate the principal resource constraints (in this case presumably light, $\mathrm{N}$, and P), and, when in short supply, may instead affect growth through Liebig's law of the minimum caused by physiological dysfunction, rather than the colimitation mechanisms proposed by Bloom et al. (1985). The proposal that ecophysiological strategies inherently favor a subset of prioritized resources is supported by the observations of Schulze (1989) to the effect that European forest decline may be brought about by tree strategies to maximize $\mathrm{N}$ and $\mathrm{C}$ acquisition to the detriment of $\mathrm{Ca}$ and $\mathrm{Mg}$ nutrition. Resource prioritization also may account for the longstanding observation that nitrogenous fertilizers may overstimulate shoot growth, inducing deficiencies of other nutrients.

Horticulturists may find the concept of VNA useful in developing management practices and genotypes that have reduced nutrient requirements. If $B$. patinoi is representative of other fruit trees, leaf frequency is an important and relatively neglected (although easily measured) determinant of nutrient allocation and light capture in canopies. The same approach could be applied to the spatial analysis of reproductive processes in canopies.

Our observations support the hypothesis that the distribution of light and $\mathrm{P}$ are correlated in the canopy of a tropical fruit tree, and suggest that leaf frequency caused by local branching, followed by changes in SLW, are the primary determinants of canopy nutrient allocation.

\section{Literature Cited}

Baker, A.S. and R.R. Smith. 1973. Preparation of solutions for atomic absorption analysis of $\mathrm{Fe}, \mathrm{Mn}, \mathrm{Zn}$, and $\mathrm{Cu}$ in plant tissue. J. Agr. Food Chem. 22: 103.
Barr, E.C. and A. Ullrich. 1963. Phosphorus fractions in high and low phosphate plants. J. Agr. Food Chem. 11:313-316.

Björkman, O. 1981. Responses to different quantum flux densities, p. 316-337. In: O.L. Lange, P.S. Nobel, C.B. Osmond, and H. Ziegler (eds.). Physiological plant ecology I. Columbia Univ. Press, New York.

Bloom A.J., F.S. Chapin, III, and H.A. Mooney. 1985. Resource limitation in plants-An economic analogy. Annu. Rev. Ecol. Systematics 16:363-392.

Bradford, M.M. 1976. A rapid and sensitive method for the quantification of microgram quantities of protein utilizing the principle of protein-dye binding. Anal. Biochem. 72:248-254.

Bremner, J.M. 1965. Total nitrogen, p. 1149-1178. In: C.A. Black, D.D. Evans, J.L. White, L.E. Ensminger, F.E. Clark, and R.C. Dinauer (eds.). Methods in soil analysis. II. Chemical and microbiological properties. Amer. Soc. of Agron., Madison, Wis.

Brooks, A. 1986. Effects of phosphorus nutrition on ribulose-1,5bisphosphate carboxylase activation, photosynthetic quantum yield and amounts of some Calvin-cycle metabolites in spinach leaves. Austral. J. Plant Physiol. 13:221-237.

Chapin, F.S., III. 1980. The mineral nutrition of wild plants. Annu. Rev. Ecol. Systematics 11:233-260.

Chapman, H.D. and P.F. Pratt. 1961. Methods of analysis for soils, plants and waters. Univ. of California, Div. of Agr. Sci., Riverside, Calif.

Charles-Edwards, D.A., H. Stutzel, R. Ferraris, and D.F. Beech. 1987. An analysis of spatial variation in the nitrogen content of leaves from different horizons within a canopy. Ann. Bot. (London) 60:421-426.

Clark, R.B. 1990. Physiology of cereals for mineral nutrient uptake, use, and efficiency, p. 131-210. In: V.C. Baligar and R.R. Duncan (eds.). Crops as enhancers of nutrient use. Academic Press, San Diego.

DeJong, T.M. 1982. Leaf $\mathrm{N}$ content and $\mathrm{CO}_{2}$ assimilation capacity in peach. J. Amer. Soc. Hort. Sci. 107:955-959.

DeJong, T.M. 1983. $\mathrm{CO}_{2}$ assimilation characteristics of five Prunus tree fruit species. J. Amer. Soc. Hort. Sci. 108:303-307.

DeJong, T.M. and J.F. Doyle. 1985. Seasonal relationships between leaf nitrogen content (photosynthetic capacity) and leaf canopy light exposure in peach (Prunus persica). Plant Cell Environ. 8:701-706.

Fassbender, H.W. and Y.K. Igue. 1967. Comparación de métodos radiométricos y colorimétricos en estudios sobre retención y transformación de fosfatos en suelo. Turrialba 17:284-287.

Field, C. 1983. Allocating leaf nitrogen for the maximization of carbon gain: Leaf age as a control on the allocation program. Oecologia 56:348-355.

Foyer, C. and C. Spencer. 1986. The relationship between phosphate status and photosynthesis in leaves. Planta 167:369-375.

Hirose, T. and M.J.A. Werger. 1987. Maximizing daily canopy photosynthesis with respect to the nitrogen allocation pattern in the canopy. Oecologia 72:520-526.

Hirose, T., M.J.A. Werger, T.L. Pons, and J.W.A van Rheenen. 1988. Canopy structure and leaf nitrogen distribution in a stand of Lysimachia vulgaris L. as influenced by stand density. Oecologia 77:145-150.

Klein, I., S.A. Weinbaum, T.M. DeJong, and T.T. Muraoka. 1991. Spur light exposure as a primary external cause for derivation of DRIS norms in walnut trees. J. Plant Nutr. 14:463-484.

Marini, R.P. and M.C. Marini. 1983. Seasonal changes in specific leaf weight, net photosynthesis, and chlorophyll content of peach leaves as affected by light penetration and canopy position. J. Amer. Soc. Hort. 
Sci. 108:600-605.

Mooney, H.A. and S.L. Gulmon. 1979. Environmental and evolutionary constraints on the photosynthetic characteristics of higher plants, $\mathrm{p}$. 316-337. In: O.T. Solbrig, S. Jain, G.B. Johnson, and P.H. Raven (eds.). Topics in plant population biology. Columbia Univ. Press, New York. Murphy, J. and J.P. Riley. 1962. A modified single solution method for the determination of phosphate in natural waters. Analytica Chimica Acta 27:31-36.

Opeke, L.K. 1982. Tropical tree crops. Wiley, New York.

Robinson, P.J. and R.G. Megarrity. 1975. Characterization of Stylosanthes introduction by using seed protein patterns. Austral. J. Agr. Res. 26:467-479.

Salinas, J.G. and R. Garcia. 1985. Metodos quimicos para el analisis de suelos acidos y plantas forrajeras. Centro Internacional de Agricultura Tropical, Cali, Colombia.

Schulze, E.D. 1989. Air pollution and forest decline in a spruce (Picea abies) forest. Science 244:745-892.

Sivak, M.N. and D.A. Walker. 1986. Photosynthesis in vivo can be limited by phosphate supply. New Phytol. 102:499-512.

Tabatabai, M.A. and J.M. Bremner. 1970. A simple turbidimetric method of determining total sulfur in plant materials. Agr. J. 62:805-806.

Vapaavuori, E.M. and A.H. Vuorinen. 1989. Seasonal variation in the photosynthetic capacity of a willow (Salix cv. Aquatica gigantea) canopy. 1. Changes in the activity and amount of ribulose 1,5-bisphosphate carboxylase-oxygenase and the content of nitrogen and chlorophyll at different levels in the canopy. Tree Physiol. 5:423-414.

Weinbaum, S.A., R.S. Johnson, and T.M. DeJong. 1992. Causes and consequences of overfertilization in orchards. HortTechnology 2:112-121.

Weinbaum, S.A., S.M. Southwick, K.A. Shackel, T.T. Muraoka, W. Krueger, and J.T. Yeager. 1989. Photosynthetic photon flux influences macroelement weight and leaf dry weight per unit of leaf area in prune tree canopies. J. Amer. Soc. Hort. Sci. 114:720-723.

Wilkinson, L. 1989. SYSTAT: The system for statistics. SYSTAT, Evanston, Ill.

Williams, J.D.H. 1967. Fractionation of soil inorganic P by a modification of Chang and Jackson's procedure. Soil Sci. Soc. Amer. Proc. 31:736-739.

Wintermans, J.F.G.M. and A. de Mots. 1965. Spectrophotometric characteristics of chlorophylls $\mathrm{a}$ and $\mathrm{b}$ and their pheophytins in ethanol. Biochimica Biophysics Acta 109:448-453. 